\title{
Effect of parallel connection of pumping units on operating costs of pumping station
}

\author{
Nazir Ikramov ${ }^{1, *}$, Eduard $\mathrm{Kan}^{1}$, Mirasil Mirzoev ${ }^{2}$, and Takhir Majidov ${ }^{1}$ \\ ${ }^{1}$ Department of Usage of water energy and pumping stations, Tashkent Institute of Irrigation and \\ Agricultural Mechanization Engineers, 100000 Kari Niyazi street, 39 Tashkent, Uzbekistan \\ ${ }^{2}$ Hydromelioration faculty, Tajik agrarian University named after Sh.Shohtemur,734003 Rudaky \\ avenue 146. Dushanbe, Tajikistan.
}

\begin{abstract}
In Uzbekistan, as well as in many other countries of the world, pumping units operate in parallel into a common pressure pipeline at some pumping stations of the irrigation system. This was done mainly to save on the capital costs of the pipeline. Analysis and hydraulic calculation of the existing large irrigation pumping stations with pumping units operating in parallel showed that at some of them the conditions of parallel operation of pumping units were impaired. As a result, a negative hydraulic process arises, in the form of self-induced vibrations of the water flow in the pipeline, which leads to various damage and deformation of the pressure pipeline and pipeline supports. The calculations showed that with different modes of pumping units operating together, the power consumption at the Amu-Bukhara-1 and Namangan pumping stations, accounting for one unit increases by $0.72 \ldots 6.53 \%$, and at the Amu-Bukhara-2 and Amu-Zang-2 pumping stations, this index, on the contrary, decreases by $0.32 \ldots 1.67 \%$. Therefore, a properly selected operating mode of parallel-connected pumping units will lead to a decrease in operating costs, i.e. decrease in the prime cost of raised water.
\end{abstract}

\section{Introduction}

Currently, a large number of pumping stations operate in the irrigation systems of Uzbekistan and other countries of the world. 1668 pumping stations operate under the Ministry of Water Management of the Republic of Uzbekistan, which include more than 5000 pumping units. The total supply of these pumping stations is about $7000 \mathrm{~m}^{3} / \mathrm{s}$, and about 2.3 million hectares are irrigated with them, which is more than $53 \%$ of all irrigated lands. Each year, about 8 billion $\mathrm{kW} \cdot \mathrm{h}$ of electricity is consumed for the operation of these pumping stations, which is about $15 \%$ of the total electricity generated in the republic per year. The age of all pumping stations is over 30 years [1]. At some pumping stations, pumping units operate in parallel and are connected to a common pressure pipeline through connecting pipelines (in order to save on the capital expenditures, at some pumping stations the pumping units are arranged in a chequered manner) and return pipeline twins

\footnotetext{
*Corresponding author: ikramov-1978@mail.ru
} 
$[2,3,4,5]$. The pressure pipelines of these pumping stations wear out due to the duration of operation on the one hand $[5,7,10]$, and on the other hand due to the inability to provide equal pump heads at their connecting nodes, i.e. on return pipeline twins $[5,10]$.

When designing pumping stations, the following hydraulic conditions were not initially provided $[1,2,5,6,7,8,9]$ such as:

- equality of the length of the connecting pipelines, since the pumping units are chequered and in order to achieve their equality, various hydraulic resistances are installed. Moreover, no sections with a uniform motion of flow L 30d are left between them, which led to an increase in the values of the local resistance coefficients, thereby increasing the equivalent length of the connecting sections;

- local hydraulic resistance - return pipeline twin, depending on the number of simultaneously operating pumping units, operates as different resistances (rotation by a certain angle, abrupt enlargement, return pipeline twin, etc.), and its value is assumed to be constant (these hydraulic properties of the return twin appear at pumping stations, where pumping units are arranged in a chequered manner, as well as on those where pumping units are located in one row).

As a result, the conditions of parallel operation of pumping units gets impaired, a negative hydraulic process occurs, in the form of self-induced vibration of water flow in the pipeline $[1,5,10]$. This leads to various damages and deformations of the pressure pipeline and its supports. So, for example, there was a breakdown of the flanges of the K-2-2 pumping station of the Tashkent region and the breakdown of fixed supports (with a rupture of the welded joint of the pipeline) of the Babatag pumping station of the Surkhandarya region. The mentioned negative hydraulic process by origin and decay time differs from the fluid line shock. Also differs from the instability of pumping units due to inconsistency of the characteristics of the pump and pipeline [1, 5, 10-20].

\section{Materials and methods}

We studied the hydraulic properties of the return pipeline twins installed on the pressure pipelines of the large pumping stations of Babatag and Amu-Zang-2 of the Surkhandarya region, Amu-Bukhara-1 and Amu-Bukhara-2 of the Bukhara region, as well as the Namangan pumping station of Namangan region. It is determined that the value of the hydraulic resistance of the return pipeline twin $[1,5,10]$ depends on the following indices:

- the number of simultaneously operating pumping units in a common pressure pipeline;

- proportionality or disproportionality of junction of flows;

- measure of the angle of junction of flows;

- cross-sectional area ratios of the (common) flows to be merged and merged.

The pressure losses on the return pipeline twin are determined by the following formulas $[2,6]$ : for direct flow passage:

$$
h_{n . n}=\frac{1}{2 g}\left(\vartheta_{0}^{2}+\vartheta_{n}^{2}-2 \frac{\omega_{n}}{\omega_{0}} \vartheta_{n}^{2}-2 \frac{\omega_{\sigma}}{\omega_{0}} \vartheta_{\sigma}^{2} \cos \alpha\right)
$$

for lateral flow passage:

$$
h_{\sigma . n}=\frac{1}{2 g}\left(\vartheta_{0}^{2}+\vartheta_{\sigma}^{2}-2 \frac{\omega_{n}}{\omega_{0}} \vartheta_{n}^{2}-2 \frac{\omega_{\sigma}}{\omega_{0}} \vartheta_{\sigma}^{2} \cos \alpha\right)
$$

here: $\vartheta_{\Pi}-$ water velocity in the direct flow, $\mathrm{m} / \mathrm{s}$;

$\vartheta_{\sigma}$ - water velocity in the lateral flow, $\mathrm{m} / \mathrm{s}$;

$\vartheta_{0}$ - water velocity in a merged (common) flow, $\mathrm{m} / \mathrm{s}$;

$\omega_{\Pi}$ - cross-section area of the direct flow, $\mathrm{m}^{2}$;

$\omega_{\sigma}$ - cross-section area of the lateral flow, $\mathrm{m}^{2}$;

$\omega_{\mathrm{o}}-$ cross-section area of the merged (common) flow, $\mathrm{m}^{2}$; 
$\mathrm{g}$ - free-fall acceleration, $\mathrm{m} / \mathrm{s}^{2}$;

$\cos \alpha$-junction angle of flows.

\section{Results and Discussion}

Calculations of the local resistance coefficient values of the return pipeline twin at these pumping stations showed that, depending on the junction angle of flows, it varies from 0.26 to 24.34. At relations of cross sections of the merged and total flows $\omega_{\text {пा }} / \omega_{0}=0.1 \div 1.0$ it makes $24 \div 0.5$ and changes when the junction angle changes from 2 to $190 \%$, and at nonproportional junction it changes by $2 \div 65 \%[1,5,10]$.

An example of the results of calculating the pressure losses and the local resistance coefficient on the return pipeline twins installed on the pressure pipeline of the Babatag pumping station (Fig. 1,2) is given in Table 1.

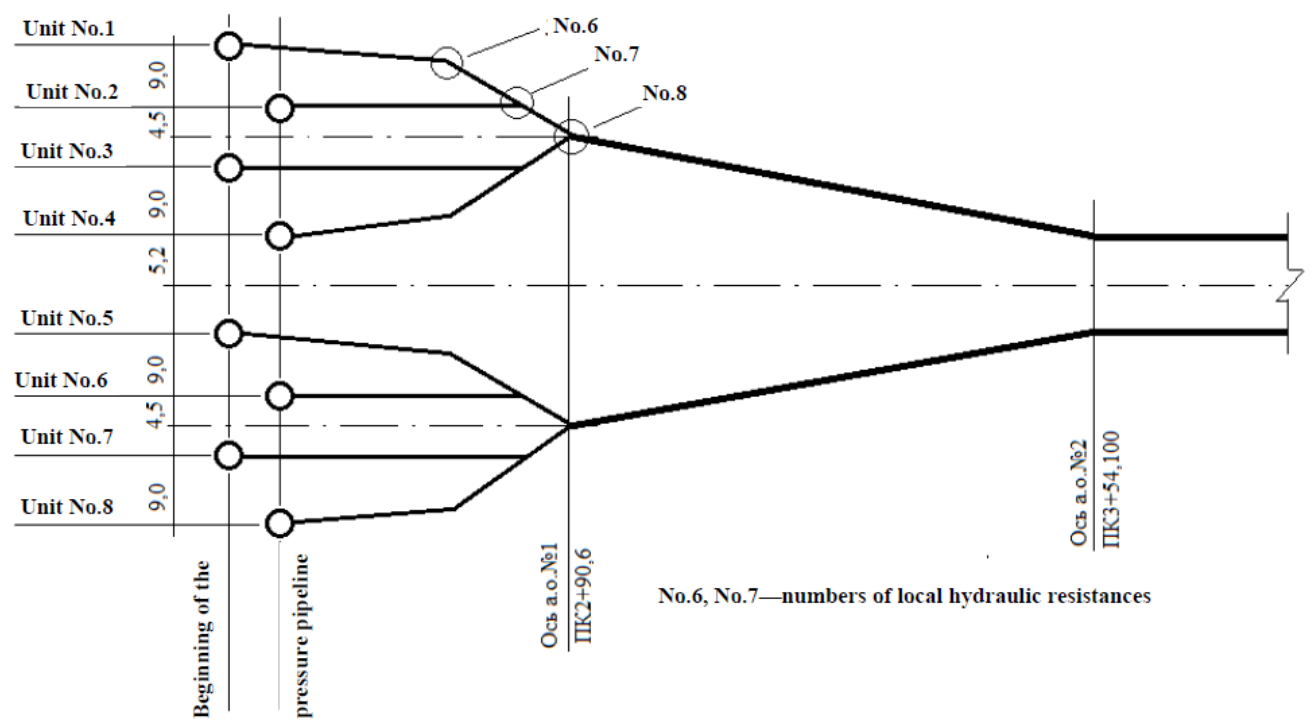

Fig. 1. Scheme of a plan of the initial section of the pressure pipeline of the Babatag pump station.

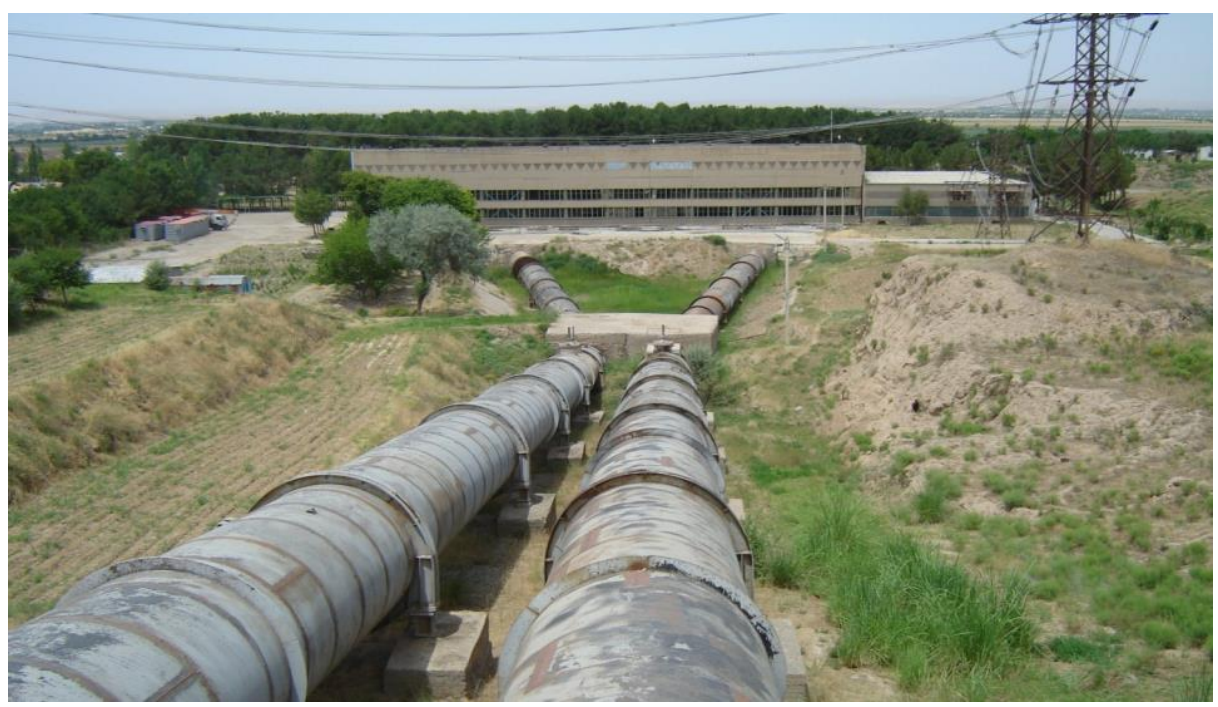

Fig. 2. Pressure pipeline of the Babatag pumping station. 
Table 1. Calculation of pressure losses and local resistance coefficient on the return pipeline twins installed on the pressure pipeline of the large Babatag pumping station

\begin{tabular}{|c|c|c|c|c|c|c|}
\hline \multirow{2}{*}{$\begin{array}{c}\text { No. of } \\
\text { simultaneously } \\
\text { operating } \\
\text { Pumping units } \\
\text { (PU) } \\
\end{array}$} & \multicolumn{3}{|c|}{$\begin{array}{c}7^{\text {th }} \text { local resistance-return pipeline } \\
\text { twin }\end{array}$} & \multicolumn{3}{|c|}{$8^{\text {th }}$ local resistance-return pipeline twin } \\
\hline & $\begin{array}{l}\text { Operating } \\
\text { conditions }\end{array}$ & $\begin{array}{c}\text { pressure } \\
\text { losses, } \\
\text { m }\end{array}$ & $\begin{array}{l}\text { resistance } \\
\text { coefficient }\end{array}$ & $\begin{array}{l}\text { operating } \\
\text { conditions }\end{array}$ & $\begin{array}{c}\text { pressure } \\
\text { losses, } \\
\mathrm{m}\end{array}$ & $\begin{array}{l}\text { resistance } \\
\text { coefficient }\end{array}$ \\
\hline PU No.1 & $\begin{array}{l}\text { operates as } \\
\text { a direct } \\
\text { section of } \\
\text { the } \\
\text { pipeline }\end{array}$ & 0 & 0 & $\begin{array}{c}\text { simultaneously } \\
\text { operates as a } \\
\text { sharp rotation } \\
\text { of pipe by } 40^{\circ} \\
\text { and abrupt } \\
\text { enlargement }\end{array}$ & 0.286 & 9.985 \\
\hline PU No.2 & $\begin{array}{l}\text { operates as } \\
\text { a sharp } \\
\text { rotation of } \\
\text { pipe by } 30^{\circ}\end{array}$ & 0.071 & 0.155 & $\begin{array}{l}\text { simultaneously } \\
\text { operates as a } \\
\text { sharp rotation } \\
\text { of pipe by } 40^{\circ} \\
\text { and abrupt } \\
\text { enlargement }\end{array}$ & 0.286 & 9.985 \\
\hline $\begin{array}{l}\text { PU No.1 and } \\
\text { No. } 2\end{array}$ & $\begin{array}{l}\text { return } \\
\text { pipeline } \\
\text { twin }\end{array}$ & 0.121 & 1.75 & $\begin{array}{c}\text { simultaneously } \\
\text { operates as a } \\
\text { sharp rotation } \\
\text { of pipe by } 40^{\circ} \\
\text { and abrupt } \\
\text { enlargement }\end{array}$ & 0.938 & 9.985 \\
\hline $\begin{array}{l}\text { PU No.1, No.2 } \\
\text { and No.3 }\end{array}$ & $\begin{array}{l}\text { return } \\
\text { pipeline } \\
\text { twin }\end{array}$ & 0.121 & 1.75 & $\begin{array}{l}\text { return pipeline } \\
\text { twin with } \\
\text { disproportionat } \\
\text { e flow junction }\end{array}$ & $\begin{array}{c}0.908 \\
\left(\mathrm{~h}_{\text {б.ก }}=\right. \\
-0.286 \\
\mathrm{~m}) \\
\end{array}$ & 4.29 \\
\hline $\begin{array}{l}\text { PU No.1, No.2, } \\
\text { No.3 and No.4 }\end{array}$ & $\begin{array}{l}\text { return } \\
\text { pipeline } \\
\text { twin }\end{array}$ & 0.121 & 1.75 & $\begin{array}{l}\text { return pipeline } \\
\text { twin }\end{array}$ & 0.774 & 2.058 \\
\hline
\end{tabular}

Analysis of table 1 shows that the value of the pressure and the resistance coefficient of the return pipeline twin varies depending on the number of simultaneously operating units. In addition, it turned out that when 3 pumps operate, a vacuum appears at the connecting node. We believe that just this is one of the reasons for the formation of a self-vibrating water motion in a pressure pipeline.

It should also be noted here that the beginning of the self-vibrating water motion in the pressure pipeline appears from the moment the pump unit is connected to an already operating network and will continue until the pressure of the pump units is equalized. We consider that this phenomenon was the cause of the breakdown of the flange connection of the K-2-2 pump station and the breakdown of the support of the Babatag pump station [1].

In addition, the calculations showed that the difference in the sum of losses of the return pipeline twin with the simultaneous operation of the pumping units No.1 and No.2 of the Babatag pumping station was $5.5 \mathrm{~cm}$. All these and previous proofs mean that the pumps operate with a predetermined mode of self-vibrating flow in the pressure pipeline.

By forming up the characteristics of a group of pumps connected to a common pressure pipeline, as well as forming up based on hydraulic calculations of the characteristics of pipelines, we determined the operating modes of the above-mentioned pumping stations. The results of the calculations are given in Table 2 . 
Table 2. Mode of operation of large pumping stations with pumping units operating in parallel into a common pressure pipeline

\begin{tabular}{|c|c|c|c|c|c|c|c|c|c|c|c|}
\hline \multirow[b]{2}{*}{$\begin{array}{l}\text { Name of } \\
\text { pumping } \\
\text { stations }\end{array}$} & \multicolumn{3}{|c|}{$\begin{array}{l}\text { With operation of } \\
1 \text { pumping unit }\end{array}$} & \multicolumn{5}{|c|}{ With operation of 2 pumping units } & \multicolumn{3}{|c|}{$\begin{array}{c}\text { With operation of } 3 \\
\text { pumping units }\end{array}$} \\
\hline & 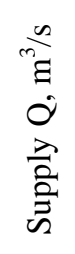 & $\begin{array}{cc}0 & \\
\vdots & \Xi \\
0 & \\
0 & = \\
\vdots & \end{array}$ & $\begin{array}{l}\dot{\overrightarrow{0}} \\
0 \\
0 \\
0\end{array}$ & 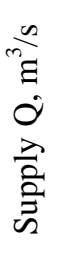 & 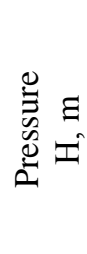 & $\begin{array}{l}\dot{\overrightarrow{0}} \\
\sum_{0}^{3}\end{array}$ & ض. & 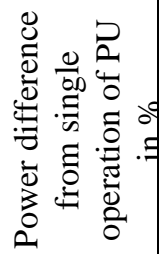 & 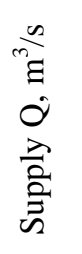 & 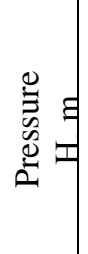 & 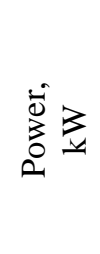 \\
\hline $\begin{array}{l}\text { Amu- } \\
\text { Bukhara- } 1\end{array}$ & 9.0 & 45 & 5155 & 17.0 & 48 & 10385 & 5192,5 & +0.72 & 24.6 & 51 & 15968 \\
\hline $\begin{array}{l}\text { Amu- } \\
\text { Bukhara-2 }\end{array}$ & 17.5 & 49 & 10914 & 34.0 & 50 & 21636 & 10818 & -0.88 & 49.5 & $\begin{array}{c}51 . \\
5\end{array}$ & 32445 \\
\hline Babatag & 4.9 & 71.5 & 4459 & 9.7 & 72 & 8889 & 4444,5 & -0.32 & 14 & 75 & 13364 \\
\hline $\begin{array}{l}\text { Amu- } \\
\text { Zang- } 2\end{array}$ & 17.4 & 49 & 10851 & 33.0 & 51.5 & 21630 & 10815 & -0.32 & - & - & - \\
\hline Namangan & 7.0 & 78 & 6946 & 13.8 & 80 & 14051 & 7025.5 & +1.10 & 20.2 & 81 & 20824 \\
\hline
\end{tabular}

Continuation of the Table 1.

\begin{tabular}{|c|c|c|c|c|c|c|c|c|c|c|c|}
\hline \multirow[b]{2}{*}{ 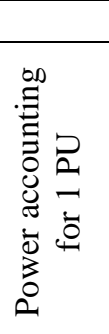 } & \multirow[b]{2}{*}{ 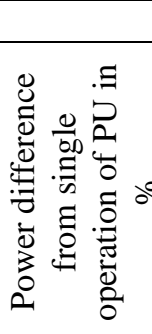 } & \multicolumn{5}{|c|}{ With operation of 4 pumping units } & \multicolumn{5}{|c|}{ With operation of 5 pumping units } \\
\hline & & 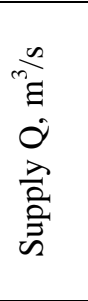 & 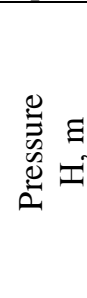 & ${ }_{0}^{0}$ & 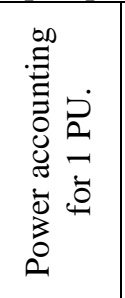 & 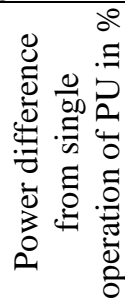 & 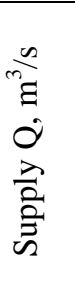 & 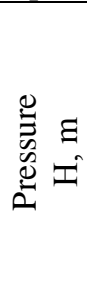 & 离 & 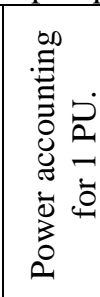 & 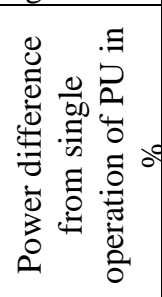 \\
\hline 5322.7 & +3.25 & 31.2 & 54.0 & 21443 & 5360.75 & +3.99 & - & - & - & - & - \\
\hline 10815 & -0.91 & 63.5 & 53.5 & 43238 & 10809.5 & -0.97 & 76.5 & 55 & 53550 & 10710 & -1.9 \\
\hline 4459.7 & +0.15 & 17.9 & 77 & 17542 & 4385.5 & -1.67 & - & - & - & - & - \\
\hline- & - & - & - & - & - & - & - & - & - & - & - \\
\hline 6941.3 & -0.11 & 25 & 82 & 26091 & 6522.75 & +6.53 & - & - & - & - & - \\
\hline
\end{tabular}

Analysis of table 2 showed that at the Amu-Bukhara-1 and Namangan pumping stations with an increase in the number of pumping units operating in parallel, the power consumed per unit increases by $0.72 \ldots 6.53 \%$. At the Amu-Bukhara-2 and Amu-Zang-2 pumping stations, this figure, on the contrary, decreases by $0.32 \ldots 1.67 \%$.

At Amu-Bukhara-1 and Namangan pumping stations, connection of pumping units to a pressure pipeline is performed through a collector. With an increase in water consumption in it, the pressure losses also increase, which leads to an increase in power accounting for one pumping unit. At Amu-Bukhara-2, Amu-Zang-2 and Babatag pumping stations, such connections performed through individual connecting pipelines and connection nodes consisting of a T-joint. Therefore, at these pumping stations, apart from the Babatag pumping station, with an increase in the number of pumping units operating in parallel, the power consumption accounted for one unit decreases. At the Babatag pumping station with parallel operation of 3 units, the power accounted for one unit increases by $0.15 \%$. This is explained by the impairment of symmetry of the poured out flows at the connection node (twin), where the lengths of the connecting pipelines are different, since the pumping units in the building of the pumping station are arranged in a chequered manner. As a result, the 
inequality of pressure at the connection node leads to the self-vibrating motion of water in the pipeline and increases the power consumption.

Hence, the connection of pumping units with a pressure pipeline through connecting pipelines and connection nodes decreases the power consumption by $0.32 \ldots 1.67 \%$. However, this leads to the emergence of self-vibrating water motion in the pipeline $[1,5,10]$, the value of which in some cases reaches the pressure in the pipeline during a hydraulic hammer. This leads to a rupture of the pipeline and an increase in operating costs. Thus, the pressure pipeline of the Babatag pumping station was damaged twice, i.e. there was a rupture of the second pipeline, and initially (in 2008) between anchor and intermediate supports No.1, then (in 2010) between anchor supports No.2 and No.3. Pipeline rupture occurred precisely in the place where the pipeline thickness was the smallest due to wear-out (corrosion, abrasive damage).

\section{Conclusions}

Self-vibrating water motion in the pressure pipeline, in the presence of connecting nodes are inevitable, they can appear in the presence of any of the above mentioned factors, both individually and in integrated effect. As a result, it can lead to various damage and deformation of the pressure pipeline and its supports.

With different modes of pumping units operating together, the power consumption at the Amu-Bukhara-1 and Namangan pumping stations, accounting for one unit increases by $0.72 \ldots 6.53 \%$, and at the Amu-Bukhara- 2 and Amu-Zang-2 pumping stations, this index, on the contrary, decreases by $0.32 \ldots 1.67 \%$. Therefore, a properly selected operating mode of parallel-connected pumping units will lead to a decrease in operating costs, i.e. decrease in the prime cost of raised water.

\section{References}

1. Tursunov T. N. and Ikramov N. M. Research report on the contractual agreement $18 / 2010$ - Evaluation of operational and energy regimes of large pumping stations (Tashkent: TIIM, 2010)

2. Robert L. Sanks, George Tchobanoglous, Bayard E. Bosserman, Garr M.Jones Pumping station design, 3rd Edition. (Butterworth-Heinemann, 2008)

3. Viholainen J., Tamminen J., Ahonen T., Ahola J., Vakkilainen E., Soukka R. Energy efficient control strategy for variable speed-driven parallel pumping systems. En. Eff., pp.495-509 (2013)

4. Jianping Guo and Lixiang Zhang. Tripping transients in a complex pumping system with multi pumps in parallel. Proc. Eng., 31, pp. 428-434 (2012)

5. Ikramov N.M. and Tursunov T.N. Factors affecting the operational and energy mode of operation of pumping stations. Materials of the International scientific-practical conference "Problems of complex arrangement of techno-natural systems", part 1 "Land reclamation, recultivation and protection of lands" (Moscow: MSLRU), pp.215220 (2013)

6. Chebaevsky V.F., Vishnevsky K.P., Nakladov N.N. Design of pumping stations and testing of pumping units. (Moscow: Kolos, 2000)

7. E.Shashi Menon and Pramila S.Menon. Working Guide to Pumps and Pumping Stations. (Calculations and Simulations Book, 2010)

8. E. Shashi Menon. Pipeline planning and construction field manual book (Elsevier Inc., 2011)

9. Stoffel B. Assessing the energy efficiency of pumps and pump units. (Elsevier Inc., 2015) 
10. Bakiyev M.R., Tursunov T.N., Ikramov N.M. About unfavourable hydraulic processes occurring at large pumping stations. Perspectives of innovation. Collection of scientific and methodical works. (Russia: SPbSPU), pp. 40-44 (2006)

11. E.W.McAllister. Pipeline rules of thumb handbook book, 8th Edition. (Gulf Professional Publishing, 2013)

12. Shankar A., Kalaiselvan V., Subramaniam U., Shanmugam P., Hanigovszki N. A comprehensive review on energy efficiency enhancement initiatives in centrifugal pumping system. Appl. Energy, 181, pp. 495-513 (2016)

13. Olszewski P. Genetic Optimization and experimental verification of complex parallel pumping station with centrifugal pumps. Appl. Energy, 178, pp. 527-539 (2016)

14. Xiangtao Zhuan, Lei Zhang, Wei Li, Fei Yang. Efficient operation of the fourth Huaian pumping station in east route of South-to-North Water Diversion Project Int. J. Of Electr. Power \& En. Sys., 98, pp. 399-408 (2018)

15. Xiangtao Zhuan, Xiaohua Xia. Optimal operation scheduling of a pumping station with multiple pumps. Appl. Energy, 104, pp. 250-257 (2013)

16. A.Mokeddem, A.Midoun, D.Kadri, S.Hiadsi, Iftikhar A.Raja. Performance of a directly-coupled PV water pumping system. En. Conver. and manag., 52(10) pp. 30893095 (2011)

17. J.I.Córcoles, J.M.Tarjuelo, M.A.Moreno. Methodology to improve pumping station management of on-demand irrigation networks. Biosys. Eng., 144, pp. 94-104 (2016)

18. V.Nenja, S.Khovanskyy, L.Gapich. Providing of the law of pumping station parameters' regulation by means of throttling elements. Proc. Eng., 39, pp. 175-181 (2012)

19. M.A.Moreno, P.A.Carrión, P.Planells, J.F.Ortega, J.M.Tarjuelo. Measurement and improvement of the energy efficiency at pumping stations. Biosys. Eng., 98(4), pp. 479-486 (2007)

20. Mazhidov T.Sh. and Ergashev A.A. The results of field studies of the pump unit with a frequency converter. Journal Irrigation and Land Reclamation, 01, p.31-34 (2016) 